
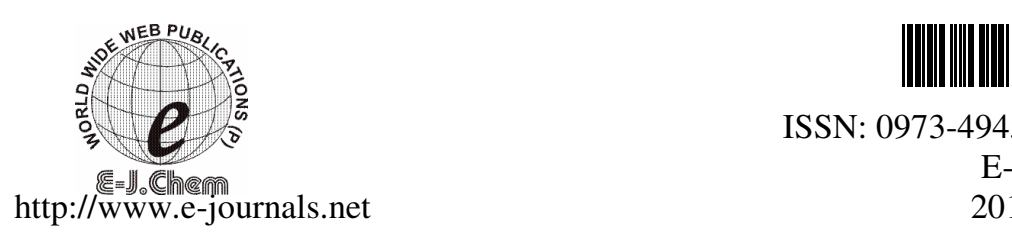

ISSN: 0973-4945; CODEN ECJHAO

E-Journal of Chemistry

2010, 7(S1), S283-S293

\title{
Determination of Bromate at Trace Level in Sudanese Bottled Drinking Water Using Ion Chromatography
}

\author{
MEI MUSA*, IBRAHIM M. AHMED ${ }^{\S}$ and ISMAT ATAKRUNI \\ *Central Laboratory \\ Ministry of Science \& Technology, Khartoum, Sudan \\ ${ }^{\S}$ Engineering Researches and Industrial Technologies \\ Ministry of Science \& Technology, Khartoum, Sudan \\ Scope Scientific Consultancy, Khartoum, Sudan \\ mai4555@hotmail.com
}

Received 15 March 2010; Accepted 23 May 2010

\begin{abstract}
Bromate ion was determined by ion chromatography with spectrophotometric detection after post column reaction with $o$-dianisidine reagent in acidic medium. IonPac AS19 anion-exchange column was used with $20 \mathrm{mM}$ sodium hydroxide eluent. The eluent from the column was then allowed to react with $o$-dianisidine at $60{ }^{\circ} \mathrm{C}$. The developed colour of the final product was measured spectrophotometrically at $450 \mathrm{~nm}$. Linearity of the method was checked up to $200 \mu \mathrm{g} / \mathrm{L}$ by using $200 \mu \mathrm{L}$ sample injection volume and the linear correlation coefficient was 0.9998 . The method detection limit was 0.56 $\mu \mathrm{g} / \mathrm{L}$ and the precision was $6.2 \%$ at $100 \mu \mathrm{g} / \mathrm{L}$. The spiked recovery for bromate in water samples was $93 \%$. Interferences from some anions eg. nitrate, chloride and nitrite were studied. The method was applied for the determination of bromate ion in ten sudanese bottled drinking water. Bromate was detected in $60 \%$ of the samples at concentrations ranged between $5-169 \mu \mathrm{g} / \mathrm{L}$.
\end{abstract}

Keywords: Bromate, Ion chromatography, Sudanese bottled water, Determination.

\section{Introduction}

Bromate in drinking water is the most commonly formed during ozonation of bromide containing waters for disinfection purposes ${ }^{1}$. Bromate can also be introduced into drinking water as a contaminant in the sodium hypochlorite used for disinfection ${ }^{2}$. International Agency of Research on Cancer (IARC) classified bromate in group B.2 (as a "probable human carcinogen") and established a drinking water maximum contaminant level goal (MCLG) of zero and maximum contaminant level (MCL) of $10 \mu \mathrm{g} / \mathrm{L}$ for bromate in finished drinking water ${ }^{3}$. The World Health Organization (WHO) has estimated an excess lifetime cancer risk of $10^{-5}$ for drinking water containing $3 \mu \mathrm{g} / \mathrm{L}$ bromate. In the U.S. EPA, the lifetime cancer risk was estimate to be $10^{-4}$ for drinking water containing $5 \mu \mathrm{g} / \mathrm{L}$ bromate ${ }^{4}$. 
With respect to these toxic effects the WHO recently established provisional guideline of $10 \mu \mathrm{g} / \mathrm{L}$ bromate in drinking water. The U.S. Environmental Protection Agency (EPA) established a maximum contaminant level of $10 \mu \mathrm{g} / \mathrm{L}$ bromate in drinking water ${ }^{3}$.

U.S. EPA Method 300.0 is an ion chromatography (IC)/ conductivity detection based method for analysis of bromate in drinking water with minimum detection limit (MDL) of $20 \mu \mathrm{g} / \mathrm{L}^{5}$. Typically, bromate peak resolution is not a problem with standard solutions. However, drinking water can contain appreciable amounts of chloride ion that can interfere with the bromate measurement ${ }^{6}$. The reduction of chloride ion and bromate ion peak overlap is possible by using a silver cartridge, large volume injection or column switching system ${ }^{6-8}$.

Simple spectrophotometric methods were used for bromate detection but these methods suffer from interference. Phenothiazones produce a coloured species following reaction with bromate under acid conditions. However, it has been noted that spectrophotometric methods using phenothiazones are suspectible to interference by humic substances found in natural water samples ${ }^{8}$. Reduced fuschin can be reacted with bromine, produced from bromate by reaction with metabisulfate. Pre-treatment is required to remove heavy metals ${ }^{9}$.

Simple and on-line spectrophotometric method was described for bromate determination by sequential injection analysis (SIA). The MDL is $0.15 \mathrm{mg} / \mathrm{L}$. This method is not suitable or determining bromate in drinking waters that arise from ozonation ${ }^{10}$.

Much lower detection limits are obtained using hyphenated techniques such as IC coupled with mass spectrometry (IC-MS), inductively coupled plasma (ICP-MS) or gas chromatographymass spectrometry $(\mathrm{GC}-\mathrm{MS})^{5,11,12,8}$. These techniques are very sensitive and single analysis is cheap, but highly sophisticated and instrumentation is expensive ${ }^{3}$.

IC coupled with post-column reaction (PCR) followed by UV-Vis detection was also used to improve detection limit ${ }^{1}$. Bromate has been detected by post-column reaction (PCR) with excess iodide under acidic conditions to form triiodide ion and detected at $352 \mathrm{~nm}$. The MDL is $0.19 \mu \mathrm{g} / \mathrm{L}^{13}$. Also $\mathrm{NaBr} / \mathrm{NaNO}_{2}$ mixture was used as post-column derivatization reagent in order to form tri-bromide, which is detected using UV detector set at $267 \mathrm{~nm}$. The MDL is less than $0.25 \mu \mathrm{g} /{ }^{\mathrm{L} 3}$. Fuchsin reacts with bromate at low $\mathrm{pH}$ to form a colour product that can be measured at $530 \mathrm{~nm}$. The MDL is $0.1 \mu \mathrm{g} / \mathrm{L}^{1}$. But those PCR systems are complicated or required additional cost for anion suppressors for the delivery of reagents ${ }^{13}$. $O$-Dianisidine (ODA) reacts with bromate to form a product that can be detected at $450 \mathrm{~nm}$. The MDL is $0.12 \mu \mathrm{g} / \mathrm{L}^{4}$. This is the simplest method among the post-column derivatization methods because it requires only a single postcolumn delivery module ${ }^{13}$.

Searching literature in local research institutes and world searching engines revealed zero study on the bromate levels in Sudanese drinking water. The aim of this paper is to validate very sensitive HPLC method for bromate ion measurement in bottled water because there is no current study done in this area in Sudan.

\section{Experimental}

All reagents used in this study were of analytical or HPLC grade and all solutions were prepared by using distilled de-ionized water. The post-column reagent was prepared by adding $40 \mathrm{~mL}$ of $70 \%$ nitric acid (Loba Chemie) to about $300 \mathrm{~mL}$ of de-ionized (DI) water in volumetric flask. $2.5 \mathrm{~g}$ potassium bromide (S.d. fine- CHEM limited, India) was added and dissolved in $100 \mathrm{~mL}$ methanol (Applichem, Germany) and was added to nitric acid/ $\mathrm{KBr}$ solution and was brought to volume with deionized water. The solution was allowed to stand overnight until the slight champagne colour fades. Then was filtered through a $0.45 \mu \mathrm{m}$ membrane filter (Millipore, USA) before use. 
A $1000 \mathrm{mg} / \mathrm{L}$ stock standard solution of bromate was prepared by dissolving $0.3260 \mathrm{~g}$ of potassium bromate (Beijing Huagongchang, China) in $250 \mathrm{~mL}$ deionized water and then stored at $4{ }^{\circ} \mathrm{C}$. Bromate working standard solutions were prepared daily by diluting the stock solution to the required concentration.

Sodium chloride (S.d. fine- CHEM limited, India), sodium nitrate (S.d. fine- CHEM limited, India) and sodium nitrite (S.d. fine- CHEM limited, India) salts were used for preparing anion stock standard solutions for interferences studies. Sodium hydroxide pellets (S.d. fine- CHEM limited, India) was used for eluent preparation $(20 \mathrm{mM})$. Then was filtered through a $0.45 \mu \mathrm{m}$ membrane filter before use.

\section{Instrumentation}

The IC used in this study was isocratic waters HPLC modified for bromate ion measurement, which consisted of a model 1515 isocratic pump, vacuum degasser and a 2996 PDA detector. The injector was a model 7725i Rheodyne injector with injection loop $200 \mu \mathrm{L}$. The analytical column used was IonPac AS19 anion exchange column with internal diameter $4 \mathrm{~mm}$ and length $250 \mathrm{~mm}$ (Dionex). The PC10 pneumatic post-column delivery module was supplied by Dionex and was equipped with reaction coil (volume $400 \mu \mathrm{L}$ ). The post-column reaction heater was from Perkin Elmer. All chromatographic results were acquired and processed by Empower software (Waters Cooperation). The experimental conditions are reported in Table 1.

Table 1. Experimental conditions

\begin{tabular}{lc}
\hline \multicolumn{1}{c}{ Column } & AS19, $4^{*} 250 \mathrm{~mm}$ \\
\hline Eluent & $20 \mathrm{mM}$ sodium hydroxide \\
Eluent Flow Rate & $0.5 \mathrm{~mL} / \mathrm{min}$ \\
Injection Volume & $200 \mu \mathrm{L}$ \\
Postcolumn Reagent Flow Rate & $0.3 \mathrm{~mL} / \mathrm{min}$ \\
Postcolumn Reagent Delivery Module & $22 \mathrm{psi}$ \\
Pressure & $400 \mu \mathrm{L}$ \\
Reaction coil volume & $60{ }^{\circ} \mathrm{C}$ \\
Postcolumn Oven Heater Temperature & PDA \\
Detector & Scanning from $400-700 \mathrm{~nm}$ and \\
Detector Wavelength & fixed at $450 \mathrm{~nm}$ \\
\hline
\end{tabular}

\section{Results and Discussion}

\section{Analytical Column}

The IonPac AS19 column is a high-capacity resin with optimized selectivity for oxyhalide anions. It is also a highly hydrophilic, hydroxide-selective anion-exchange column. It was used as a separation column for the determination of levels of bromate in drinking water ${ }^{14}$. In this study, the IonPac AS19 column was selected to improve the performance of ion chromatography methods and allows selective separation for bromate ion.

\section{Postcolumn delivery module}

To enhance the sensitivity and selectively of the method, bromate ion eluting from the column was reacted with the post-column reagent $o$-dianisidine to give coloured compound measured at $450 \mathrm{~nm}$. This post-column reagent was delivered smoothly to system by using 
pneumatic delivery module. The most advantage of this pneumatic delivery system is to minimize the baseline noise which is an inherited problem when using pumps. Minimizing the base line noise will improve the method detection limit.

\section{Reaction coil}

Two types of reaction coils made from polyetheretherketone (peek) tube were tried in this study to established the optimum tube volume that can give best response; one reaction coil used in the preliminary study has 0.02 in. i.d. $\times 29.9$ in. length $(154 \mu \mathrm{L})$ and the other reaction coil has 0.03 in. i.d. $x$ and 34.57 in length $(400 \mu \mathrm{L})$.

This preliminary study revealed that the reaction coil with 0.02 in. i.d. $\times 29.9$ in. length caused back pressure with flow rates above $0.5 \mathrm{~mL} / \mathrm{min}$ and $0.2 \mathrm{~mL} / \mathrm{min}$ flow rate for mobile phase and postcolumn reagent respectively. Preliminary results obtained by this reaction coil were done at flow rate $0.5 \mathrm{~mL} / \mathrm{min}$ for mobile phase and $0.2 \mathrm{~mL} / \mathrm{min}$ for post-column reagent. However lower sensitivity results obtained using this reaction coil.

Since this work aimed for obtaining a sensitive method for bromate determination; the reaction coil with 0.03 in. i.d. $x$ and 34.57 in length was found to give the optimal condition for good bromate sensitivity and low back pressure. This because of the increased reaction coil volume and diameter. When 0.02 in. i.d. reaction coil was used the peak area is lower than peak area obtained by using 0.03 in. i.d. as shown in Table 2.

Table 2. Peak area of $100 \mu \mathrm{g} / \mathrm{L}$ bromate standard solution using different reaction coil internal diameters

\begin{tabular}{ccc}
\hline Injection & Peak area obtained by using & \multicolumn{2}{c}{ Peak area obtained by using } \\
No & $154 \mu \mathrm{L}$ reaction coil, $\mu \mathrm{V}$ sec & $400 \mu \mathrm{L}$ Reaction coil, $\mu \mathrm{V} \mathrm{sec}$ \\
\hline 1 & 71080 & 334847 \\
2 & 77018 & 303852 \\
3 & 79553 & 318539 \\
\hline
\end{tabular}

\section{Column heater}

The reaction of bromate with $o$-dianisidine reagent is slow at ambient temperature. A postcolumn heater was used to increase the reaction rate.

\section{Sample volume}

Large volume injection loop $200 \mu \mathrm{L}$ was used to enhance the detector sensitivity.

\section{Optimization of chromatographic parameters}

All experiments done for optimization chromatographic parameters were done by using $100 \mu \mathrm{g} / \mathrm{L}$ bromate standard solution. For individual parameter study the other parameters were fixed and the studied parameter was changed.

\section{Effect of the mobile phase flow rate}

The effect of eluent flow rate on bromate peak retention time and recovery was studied using mobile phase flow rates ranging from $0.3-0.7 \mathrm{~mL} / \mathrm{min}$ as shown in Table 3 . Calculated concentrations of bromate standard at different mobile phase flow rates are plotted against eluent flow rate as shown in Figure 1. As expected the bromate peak retention time is decreased with increased mobile phase flow rate. Also from Table 3 it appears that the flow 
rates $0.3,0.4$ and $0.5 \mathrm{~mL} / \mathrm{min}$ has no effect on bromate recovery $(>96 \%)$ but flow rate greater than $0.5 \mathrm{~mL} / \mathrm{min}$ decreased detector response hence decreased bromate recovery. This may be due to less contact time between bromate and $o$-dianisidine reagent. Eluent flow rate of $0.5 \mathrm{~mL} / \mathrm{min}$ was selected in this study because at this flow rate optimum response is obtained as well as suitable retention time.

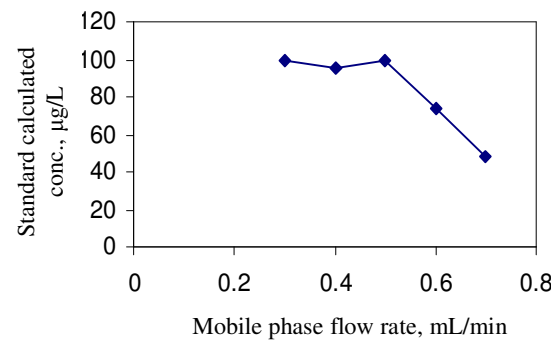

Figure 1. Plot of bromate standard calculated concentration against the eluent flow rate chromatographic conditions are listed under experimental conditions

Table 3. Effect of the mobile phase flow rate on bromate standard concentration and retention time (RT)

\begin{tabular}{cccc}
\hline $\begin{array}{c}\text { Mobile phase } \\
\text { flow rate, } \mathrm{mL} / \mathrm{min}\end{array}$ & $\begin{array}{c}\text { Bromate standard } \\
\text { conc., } \mu \mathrm{g} / \mathrm{L}\end{array}$ & $\begin{array}{c}\text { Bromate standard } \\
\text { Calculated conc. } \pm \mathrm{SD}^{\mathrm{a}} \mu \mathrm{g} / \mathrm{L}\end{array}$ & $\begin{array}{c}\text { Bromate peak } \\
\mathrm{RT}, \mathrm{min}\end{array}$ \\
\hline 0.3 & 100 & $99 \pm 0.4$ & 15.76 \\
0.4 & 100 & $96 \pm 3.1$ & 11.93 \\
0.5 & 100 & $99 \pm 2.1$ & 9.45 \\
0.6 & 100 & $77 \pm 6.6$ & 7.82 \\
0.7 & 100 & $48 \pm 7.0$ & 6.77 \\
\hline
\end{tabular}

\section{Effect of the post-column reagent (PCR) flow rate}

$o$-Dianisidine reagent was used as post-column reagent to enhance sensitivity and selectivity of bromate determination. The flow rate of post-column reagent was studied between $0.1-0.6 \mathrm{~mL} / \mathrm{min}$. Figure 2 shows the effect of post-column reagent flow rate on sensitivity. From this experimental data a flow rate of $0.3 \mathrm{ml} / \mathrm{min}$ was selected for further studies as it gives the most sensitive response. It was found that the eluent flow rate to $o$-dianisidine PCR flow rate ratio is 1.7 ; it is close to the optimum ratio provided ${ }^{4}$ in EPA method 317.0 which is 1.9 .

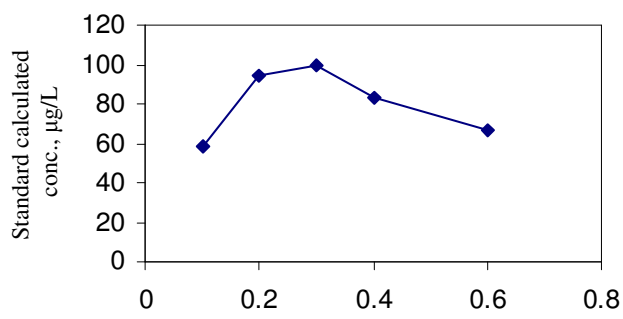

Post-column flow rate, $\mathrm{mL} / \mathrm{min}$

Figure 2. Plot of bromate conc. against the PCR flow rate chromatographic conditions are listed under experimental conditions 


\section{Interference Study}

\section{Nitrate}

The interferences effect from some anions was studied. It was found that nitrate dose not interfere at 1000 and $2500 \mu \mathrm{g} / \mathrm{L}$ concentration levels. It was postulated that, possibly nitrate did not react with $o$-dianisidine reagent under the experimental conditions set in this study.

\section{Chloride}

In this work chloride interference was studied by using $100 \mu \mathrm{g} / \mathrm{L}$ bromate standard solutions containing chloride ion at concentrations 100,400 and $600 \mathrm{mg} / \mathrm{L}$. It was found that at $100 \mathrm{mg} / \mathrm{L}$ chloride ion has no effect on the bromate peak, however, at concentrations higher than $100 \mathrm{mg} / \mathrm{L}$, the bromate peak became broad and an increase in the baseline noise level was noticed as shown in Figure 3.

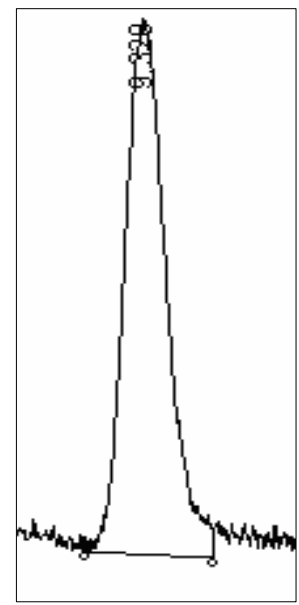

$100 \mu \mathrm{g} / \mathrm{L} \mathrm{BrO}_{3}^{-}$ $100 \mathrm{mg} / \mathrm{L} \mathrm{Cl}^{-}$

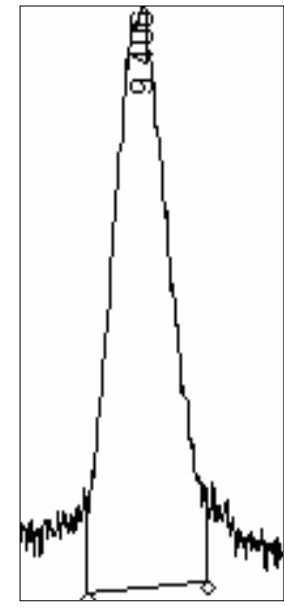

$100 \mu \mathrm{g} / \mathrm{L} \mathrm{BrO}_{3}^{-}$ $400 \mathrm{mg} / \mathrm{L} \mathrm{Cl}^{-}$

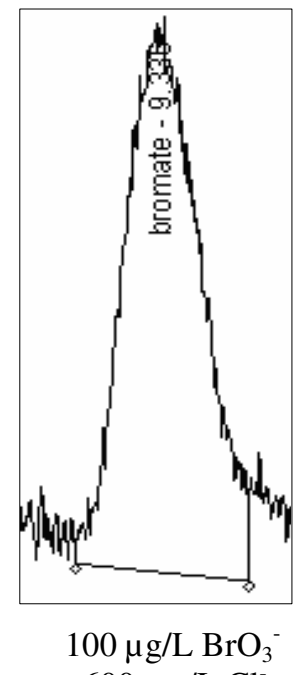

$600 \mathrm{mg} / \mathrm{L} \mathrm{Cl}^{-}$

Figure 3. Effects of chloride ion on the bromate ion peak chromatographic conditions are listed under experimental conditions

This could be explained by the fact that high concentrations of chloride ion cause column overloading that limits available binding sites on the analytical column for bromate ion and causes bromate ion peak broadening. The broad, asymmetric peak presents a problem in that an unbiased decision may be made of how to assign the bromate ion peak baseline ${ }^{11}$.

\section{Nitrite}

Nitrite ion interference was studied by using $100 \mu \mathrm{g} / \mathrm{L}$ bromate standard solutions containing nitrite ion at concentrations 100 and $300 \mu \mathrm{g} / \mathrm{L}$ it was found that nitrite, was detected whithout interferance with bromate at these levels (RT 9.2 and $12.4 \mathrm{~min}$ for bromate and nitrite respectively). However the response for the nitrite ion is low at $450 \mathrm{~nm}$ Figure 4, higher response was observed at wavelenghth $400 \mathrm{~nm}$ with reduction in bromate ion peak response Figure 5. This result indicate that the suitable wavelenghth for bromate detection and quantification is $450 \mathrm{~nm}$. On the other hand $400 \mathrm{~nm}$ is suitable for nitrite detection and quantification. 


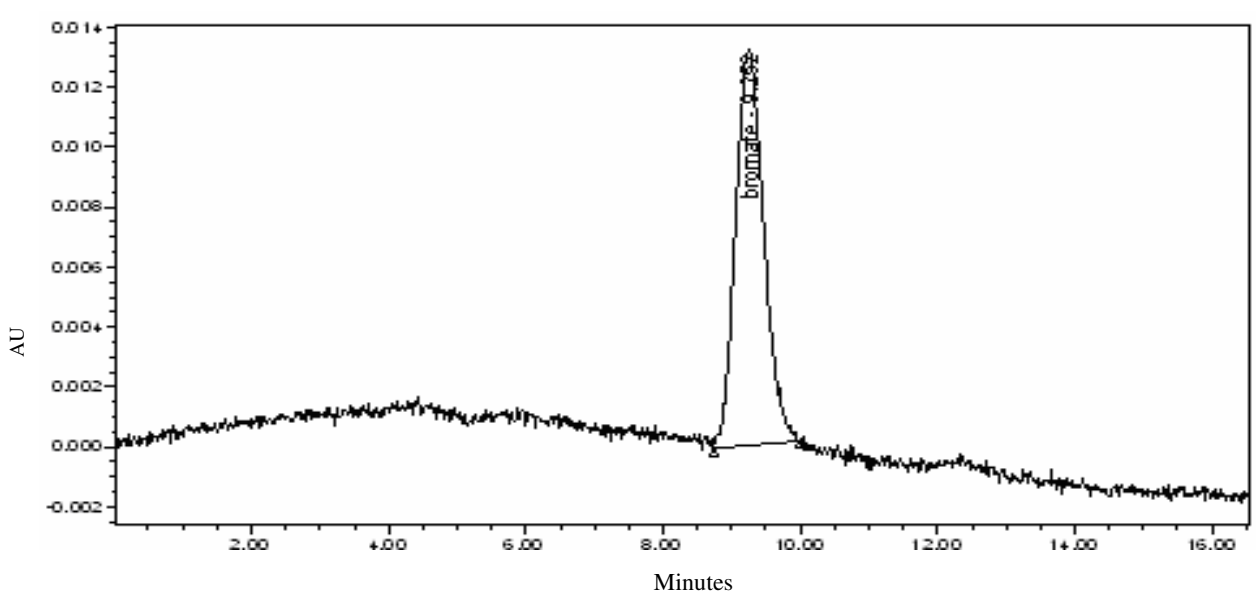

Figure 4. Analysis of mixture of $100 \mu \mathrm{g} / \mathrm{L}$ bromate standard and $100 \mu \mathrm{g} / \mathrm{L}$ nitrite solution with HPLC system, chromatographic conditions are listed under experimental conditions, wavelength $450 \mathrm{~nm}$

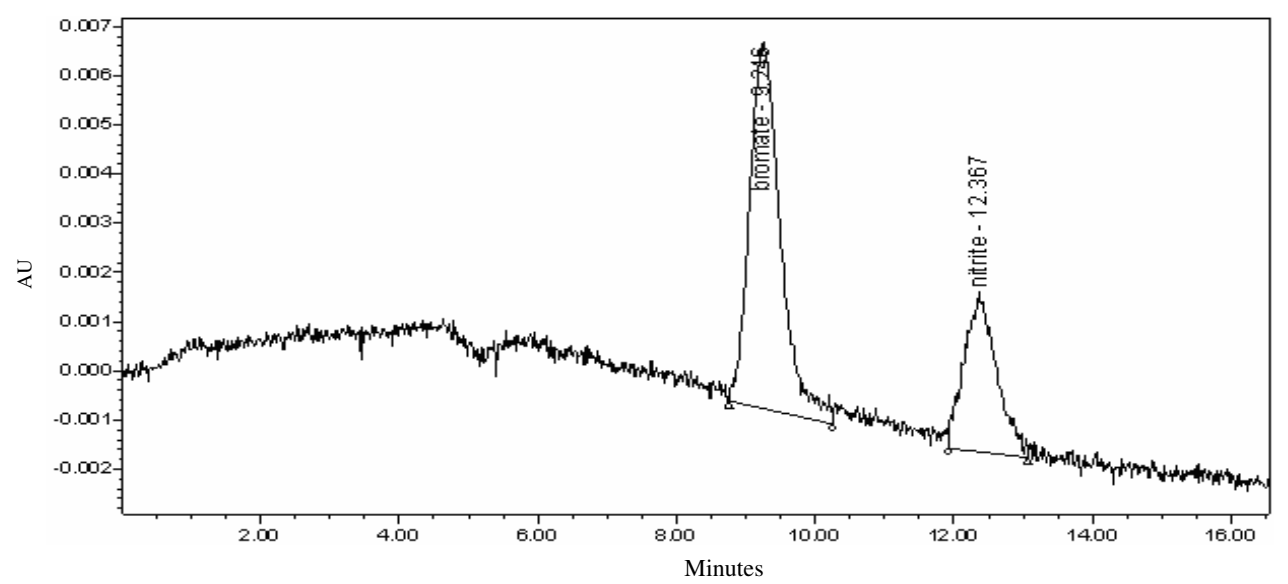

Figure 5. Analysis of mixture of $100 \mu \mathrm{g} / \mathrm{L}$ bromate standard and $100 \mu \mathrm{g} / \mathrm{L}$ nitrite solution with HPLC system, chromatographic conditions are listed under experimental conditions, wavelength $400 \mathrm{~nm}$

\section{Method Calibration}

\section{Linearity}

The calibration graphs were generated using $200 \mu \mathrm{L}$ injection loop. Six different concentrations of bromate from $10 \mu \mathrm{g} / \mathrm{L}$ to $200 \mu \mathrm{g} / \mathrm{L}$ were analyzed four times according to the optimized experimental conditions. Then the calibration curve was established according to the obtained response (peak area) and the concentrations of the bromate in the standard solutions. The results showed a good linear relationship. The calibration data was summarized in Table 4. The calibration graph is shown in Figure 6.

Table 4. Regression data and statistical parameters for bromate calibration

\begin{tabular}{cccc}
\hline Correlation coefficient, $\mathrm{R}^{2}$ & Slope, $\mathrm{m}$ & $y$-Intercept & Linear Range, $\mu \mathrm{g} / \mathrm{L}$ \\
\hline 0.9998 & 3037.4 & -1372 & $1.9-200$ \\
\hline
\end{tabular}




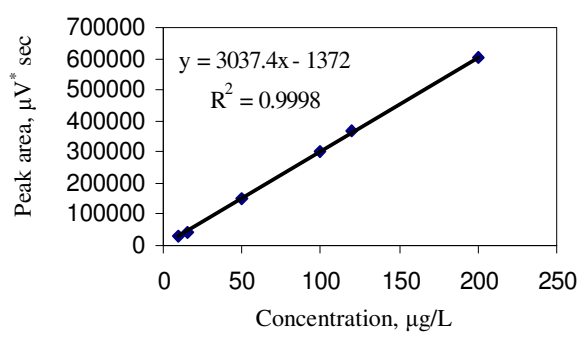

Figure 6. Bromate ion calibration curve

\section{Method detection and quantification limits}

Table 5 summerizes the method detection limit (MDL) and method quantification limit (MQL) MDL was estimated as $3 \sigma$ (the standard deviation of the baseline noise) and MQL was calculated by multiplying $\sigma$ by $10^{1}$.

Table 5. Method detection and quntification limits for bromate ${ }^{a}$

\begin{tabular}{ccc}
\hline $\begin{array}{c}\sigma \text { for seven } \\
\text { replicates, } \mu \mathrm{g} / \mathrm{L}\end{array}$ & $\begin{array}{c}\text { Calculated MDL }^{\mathrm{b}} \\
\mu \mathrm{g} / \mathrm{L}\end{array}$ & $\begin{array}{c}\text { Calculated } \\
\mathrm{MQL}^{\mathrm{c}}, \mu \mathrm{g} / \mathrm{L}\end{array}$ \\
\hline 0.186 & 0.56 & 1.9 \\
\hline
\end{tabular}

${ }^{a}$ Standard Concentration was $10 \mu \mathrm{g} / \mathrm{L},{ }^{b} \mathrm{MDL}$, limit of detection $(3 \sigma) .{ }^{c}{ }^{c} \mathrm{MQL}$, limit of quantification $(10 \sigma)$

\section{Precision}

The precision of the system was evaluated by estimating the percent relative standard deviation (\%RSD) of four successive determinations for $100 \mu \mathrm{g} / \mathrm{L}$ bromate standard. It was found that the precision of the system is $6.2 \%$.

\section{Method validation}

The validity of this method was checked by evaluating recovery using spike addition method. For recovery study two types of known bromate concentration bottled water labeled as 7 and 9 were spiked with $100 \mu \mathrm{g} / \mathrm{L}$ of bromate standard and recovery was calculated as summarized in Table 6.

Table 6. Recovery of bromate from spiked bottled water samples

\begin{tabular}{ccccc}
\hline $\begin{array}{c}\text { Sample } \\
\text { No. }\end{array}$ & $\begin{array}{c}\text { Amount }{ }^{\text {a }} \text { of bromate } \\
\text { in sample } \mu \mathrm{g} / \mathrm{L}\end{array}$ & $\begin{array}{c}\text { Amount of bromate } \\
\text { added } \mu \mathrm{g} / \mathrm{L}\end{array}$ & $\begin{array}{c}\text { Amount of bromate } \\
\text { found, } \mu \mathrm{g} / \mathrm{L}\end{array}$ & $\begin{array}{c}\text { Recovery } \\
\text { percentage, } \%\end{array}$ \\
\hline 7 & $81 \pm 3.2$ & 100 & $170 \pm 2.9$ & 89 \\
9 & $66 \pm 1.6$ & 100 & $163.6 \pm 4.2$ & 96.4 \\
\hline \multicolumn{5}{c}{${ }^{\text {a Average } \pm \text { Standard deviation }(n=3)}$}
\end{tabular}

As shown in Table 6 bromate recoveries in water samples were in the range of $89-96.4 \%$ of a mean recovery of $93 \%$, well within the $75-125 \%$ acceptance criteria ${ }^{4}$ of method 317.0 .

\section{Application of the method}

The validated method was used to determine the concentration of bromate ion in real samples (bottled water samples final product). Chromatograms of bottled water labeled 3 and $100 \mu \mathrm{g} / \mathrm{L}$ bromate ion standard are reported in Figure 7 and Figure 8 respectively. All samples injections were done at optimized conditions. All samples results were an averge of four determinations as reported in Table 7. 


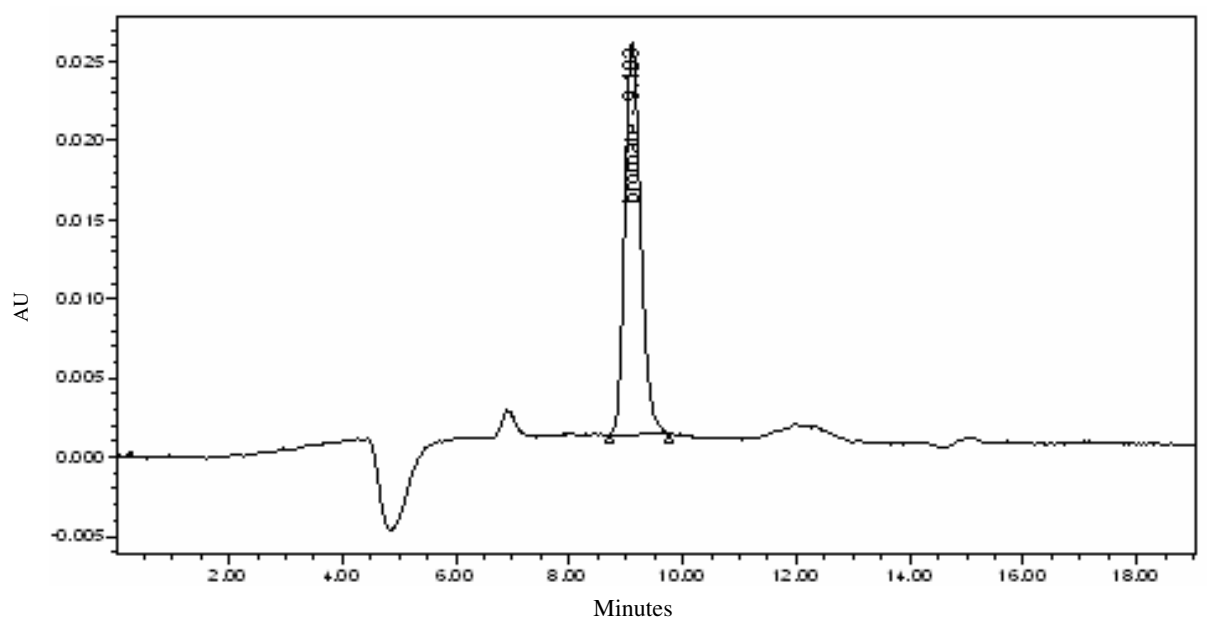

Figure 7. Chromatogram of bottled water (Sample No.3), chromatographic conditions are listed under experimental conditions

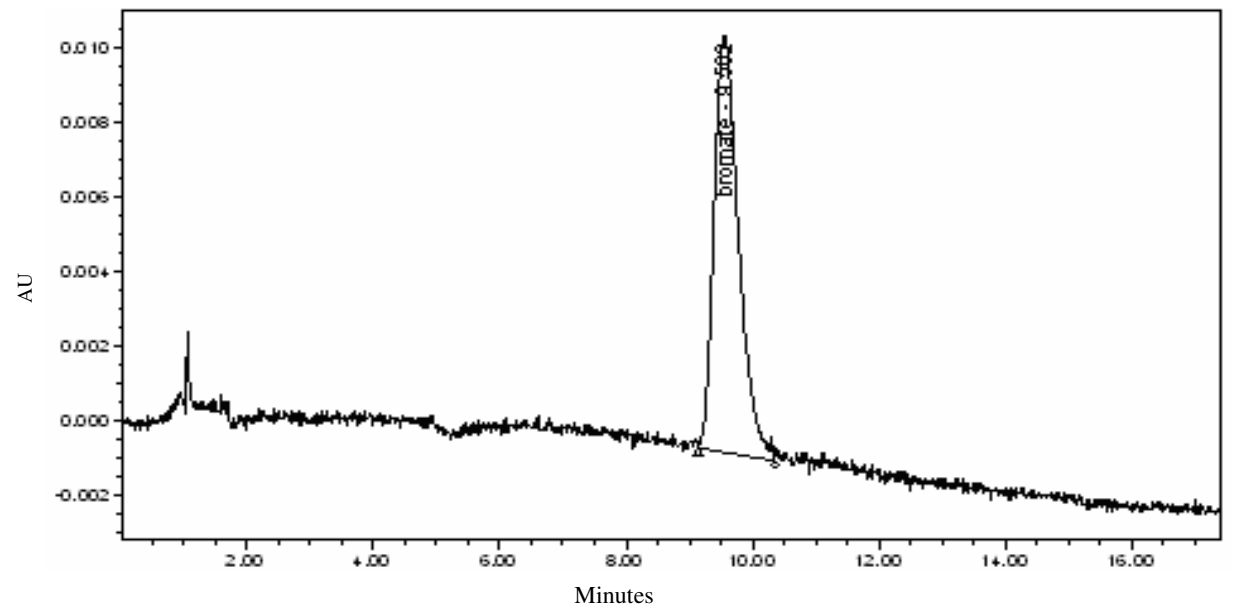

Figure 8. Chromatogram of $100 \mu \mathrm{g} / \mathrm{L}$ bromate ion, standard solution chromatographic conditions are listed under experimental conditions

Table 7. Bromate concentration in water samples

\begin{tabular}{cc}
\hline Sample No & Bromate conc. Mean $\pm \mathrm{SD}^{\mathrm{a}}, \mu \mathrm{g} / \mathrm{L}$ \\
\hline 1 & $67.0 \pm 2.7$ \\
2 & $18.2 \pm 1.6$ \\
3 & $160.0 \pm 5.3$ \\
4 & $169.0 \pm 4.6$ \\
5 & $<0.56^{\mathrm{b}}$ \\
6 & $<0.56$ \\
7 & $60.0 \pm 9.8$ \\
8 & $5.4 \pm 0.9$ \\
9 & $<0.56$ \\
10 & $<0.56$ \\
\hline
\end{tabular}

${ }^{a}:$ Standard deviation of 4 runs, $^{b}$ : Less than method detection limit $(M D L)$ 
The bromate ion concentrations in bottled water samples were found ranging from less than MDL to $169 \mu \mathrm{g} / \mathrm{L}$. In five samples the concentration of bromate ion is higher than the maximum contaminant level $(10 \mu \mathrm{g} / \mathrm{L})$ established by $\mathrm{WHO}^{4}$. This high level of bromate may be due to high bromide concentrations in water sources or due to oxidation of bromide impurities arising from disinfection by sodium hypochlorite as most bottled water factories in Sudan use sodium hypochlorite in water disinfection beside ozone. In water sample labeled 5,6, 8 and 10 bromate concentration was less than method detection limit; this could be due to the fact that ozone was used only for washing bottles and not used for final product disinfection. Also bromate was not detected in water sample labeled 9 because the source was tab water (river water).

For all samples bromate peak purity was checked to determine if a peak was spectrally homogeneous or not as shown in Table 8. It appeared that from Table 8 that all bromate peaks are spectrally homogeneous because in all peaks the purity angle is less than the purity threshold and this means that there is no coelution ${ }^{15}$.

Table 8. Bromate peak purity in water samples

\begin{tabular}{ccc}
\hline Sample No. & Purity angle & Purity threshold \\
\hline 1 & 1.62 & 2.43 \\
2 & 11.03 & 12.73 \\
3 & 2.67 & 9.29 \\
4 & 2.24 & 5.56 \\
7 & 5.08 & 10.89 \\
8 & 32.86 & 90 \\
\hline
\end{tabular}

\section{Comparison between this study and previous studies}

The method detection limit (MDL) of this present method is higher than the MDL of previous IC-PCR methods because sample injection volume $(200 \mu \mathrm{L})$ and reaction coil volume $(400 \mu \mathrm{L})$ which were used in this method is less than that used in pervious methods (500 $\mu \mathrm{L}$ for injection loop and reaction coil). But this method is more sensitive than the IC-CD because conductivity detector is inherent insensitive. Also this method is more sensitive than spectrophotometeric method because the separation enhances the sensitivity. Percentage recoveries and linearity are comparable for all methods. The (RSD\%) of this method less than of the previous IC-PCR $\left(\mathrm{NaBr}-\mathrm{NaNO}_{2}, \mathrm{KI}-\left(\mathrm{NH}_{4}\right)_{6} \mathrm{Mo}_{7} \mathrm{O}\right)$ methods and IC-CD, but it higher than IC-PCR (ODA).

Table 9. Figure of merits of techniques used in bromate analysis

\begin{tabular}{|c|c|c|c|c|c|c|}
\hline \multirow{3}{*}{ 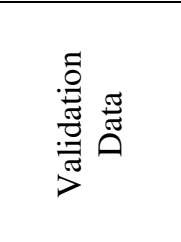 } & \multicolumn{5}{|c|}{ Previous Studies } & \multirow{2}{*}{$\begin{array}{c}\begin{array}{c}\text { Present } \\
\text { Study }\end{array} \\
\text { IC-PCR } \\
\end{array}$} \\
\hline & \multirow{2}{*}{ IC-CD ${ }^{16}$} & \multicolumn{3}{|c|}{ IC-PCR } & $\begin{array}{c}\text { Spectro- } \\
\text { photometery }\end{array}$ & \\
\hline & & $\mathrm{ODA}^{4}$ & $\begin{array}{c}\mathrm{NaBr}- \\
\mathrm{NaNO}_{2}{ }^{13} \\
\end{array}$ & $\begin{array}{c}\mathrm{KI}-\left(\mathrm{NH}_{4}\right)_{6} \\
\mathrm{Mo}_{7} \mathrm{O}^{13}\end{array}$ & Fuchsin ${ }^{9}$ & ODA \\
\hline $\mathrm{MDL}, \mu \mathrm{g} / \mathrm{L}$ & 1.73 & 0.14 & 0.17 & 0.19 & 1 & 0.56 \\
\hline RSD\% & 12.55 & 4.5 & 7.5 & 8.4 & 6 & 6.2 \\
\hline Recovery \% & - & 104.8 & 94 & 104 & - & 93 \\
\hline Linearity & 0.9998 & 0.9996 & 0.9990 & 0.9999 & 0.9990 & 0.9998 \\
\hline
\end{tabular}




\section{Conclusion}

In this study, sensitive high performance liquid chromatography method for the determination of trace levels of bromate in water was developed. This method involved the use of a hydroxide-selective IonPac AS19 and large volume injection. This method used spectrophotometric detection after postcolumn reaction with $o$-dianisidine to improve selectivity and sensitivity of determination of bromate ion. The method detection limit is 0.56 $\mu \mathrm{g} / \mathrm{L}$ and the precision is $6.2 \%$ at $100 \mu \mathrm{g} / \mathrm{L}$ level. The spiked recoveries for bromate in water samples were 93. This method could be applied to check of European Union (EU) limit values for bromate in drinking water $(10 \mu \mathrm{g} / \mathrm{L})$, without preconcentration steps or clean-up to remove interferences. This method is not influenced by interference from nitrate at concentration 2500 $\mu \mathrm{g} / \mathrm{L}$ and chloride at concentration less than $100 \mathrm{mg} / \mathrm{L}$. Also this validated method can detect nitrite ion in water. Results showed that in some water samples different concentrations of bromate were detected. This work with the very low bromate sensitivity obtained $(0.56 \mu \mathrm{g} / \mathrm{L})$ is considered a pioneer work in Sudan according to available facilities. It could be used as altranative method for the less sensitive methods used.

\section{References}

1. Achilli M and Romele L, J Chromatogr A, 1999, 847, 271-277.

2. Thomas Bonacquisti P, Toxicol., 2006, 221(2-3),145-148.

3. Michalski R, Polish J Environ Studies, 2003, 12(6), 727-734.

5. Creed J T, Magnuson M L and Brochoff C, Environ Sci Technol., 1997, 31, 2059-2063.

6. Yuan Huang, Shi-Fen Mou and Yan Yan, J Liq Chromatogr Relat Technol.,1999, 22(14), 2235-2245.

7. Peter E Jackson and Kirk Chassaniol, J Environ Monit., 2002, 4, 10-15.

8. Ray Butler, Lucy Lytton, Andrew R. Godley, Ibtisam E. Tothilla and Elise Cartmell, J Environ Monit., 2005, 7, 999-1006.

9. Romele L and Achilli M, Analyst, 1998, 123(2), 291-294.

10. van Staden J F, Mulaudzi L V and Stefan R I, Talanta, 2004, 64(5), 1196-1202.

11. Silvano Cavalli, Stefano Polesello, Sara Valsecchi, J Chromatogr A, 2005, 1085(1), 42-46.

12. Roehl R, Slingsby R, Avdalovic N and Jackson P E, J Chromatogr A, 2002, 956(1-2), 245-254.

13. Shinya Echigo, Roger A Minear, Harumi Yamada and Peter E Jackson, J Chromatogr $A$, 2001, 920(1-2), 205-211.

14. De Borba B M, Rohrer J S, Pohl C A and Saini C, J Chromatogr A, 2005, 1085(1), 23-32.

15. Waters Empower PDA Software getting started guide (Waters corporation. Printed in the USA, 34 Maple street, Milford, MA 01757), 2002.

16. Dionex Corporation, Sunnyvale, CA, Application Note 81; Ion Chromatography Determination of oxyhalides and Bromide at Trace Level Concentration in Drinking Water Using Direct Injection, 1997. 


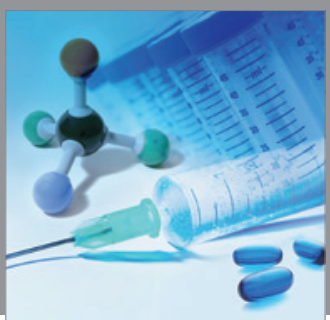

International Journal of

Medicinal Chemistry

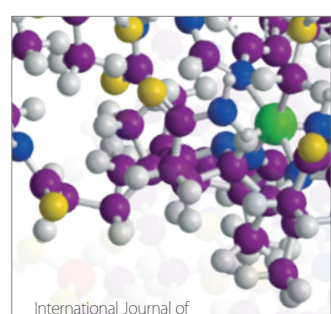

Carbohydrate Chemistry

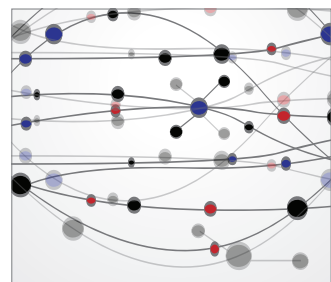

The Scientific World Journal
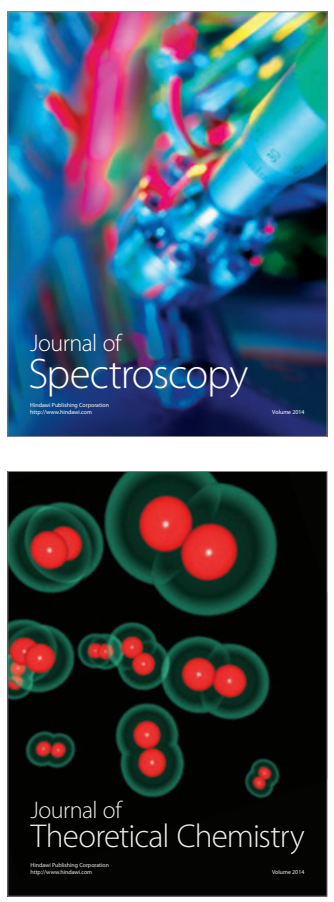
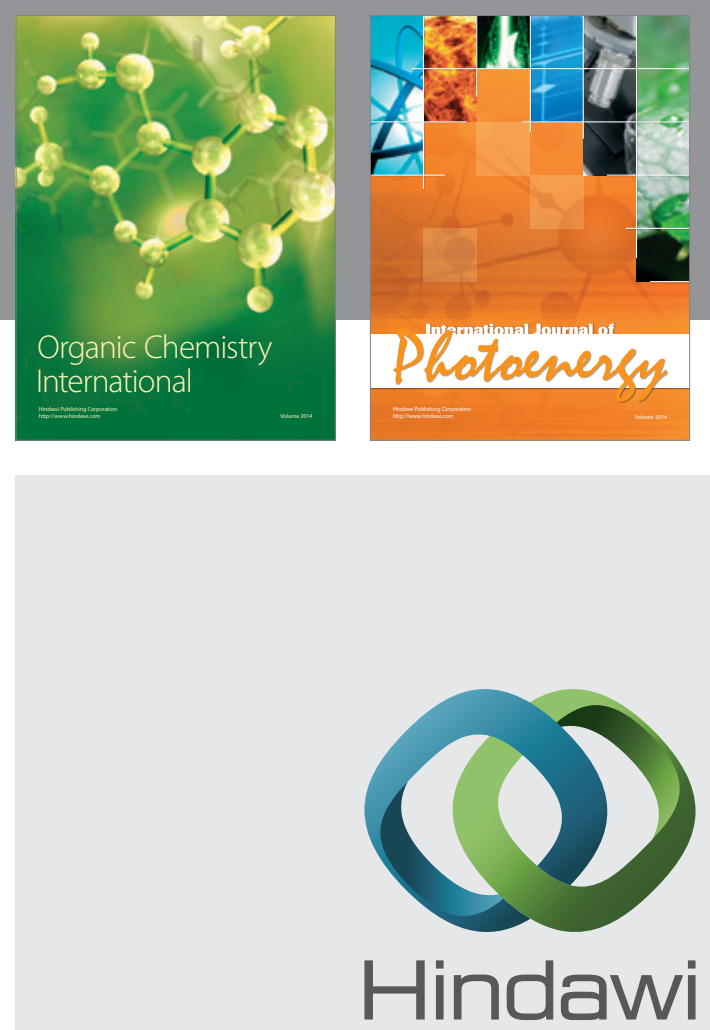

Submit your manuscripts at

http://www.hindawi.com
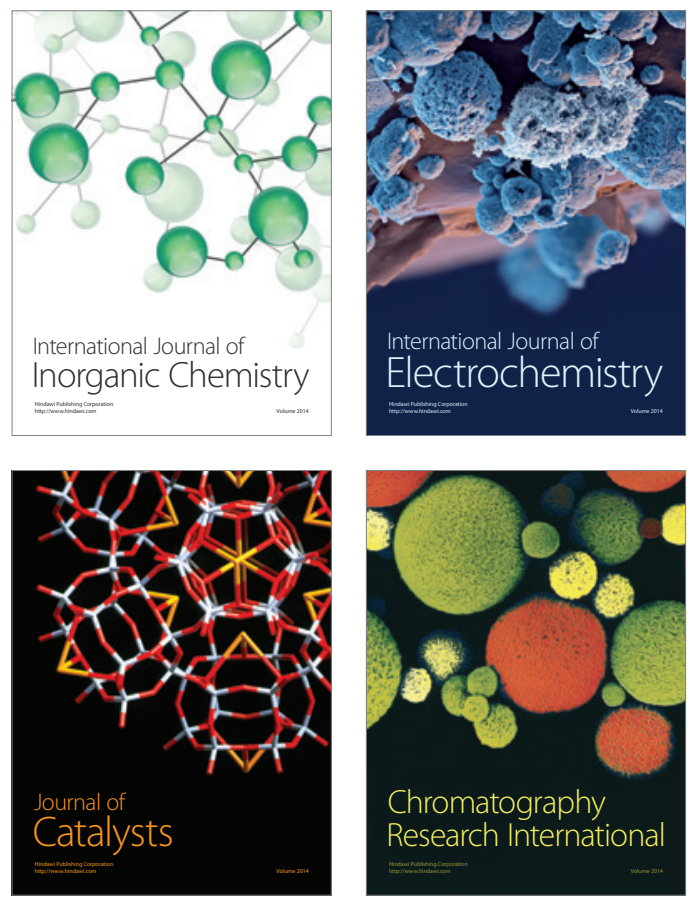
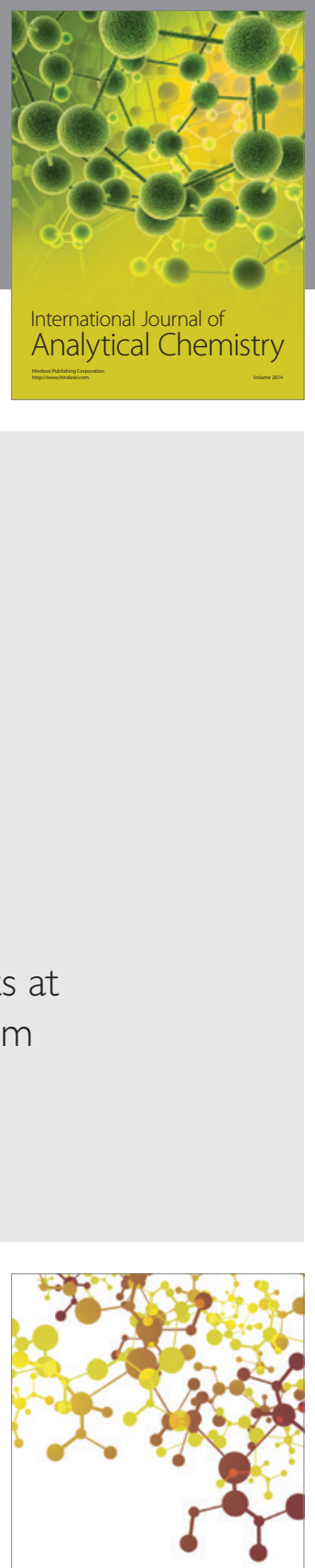

Journal of

Applied Chemistry
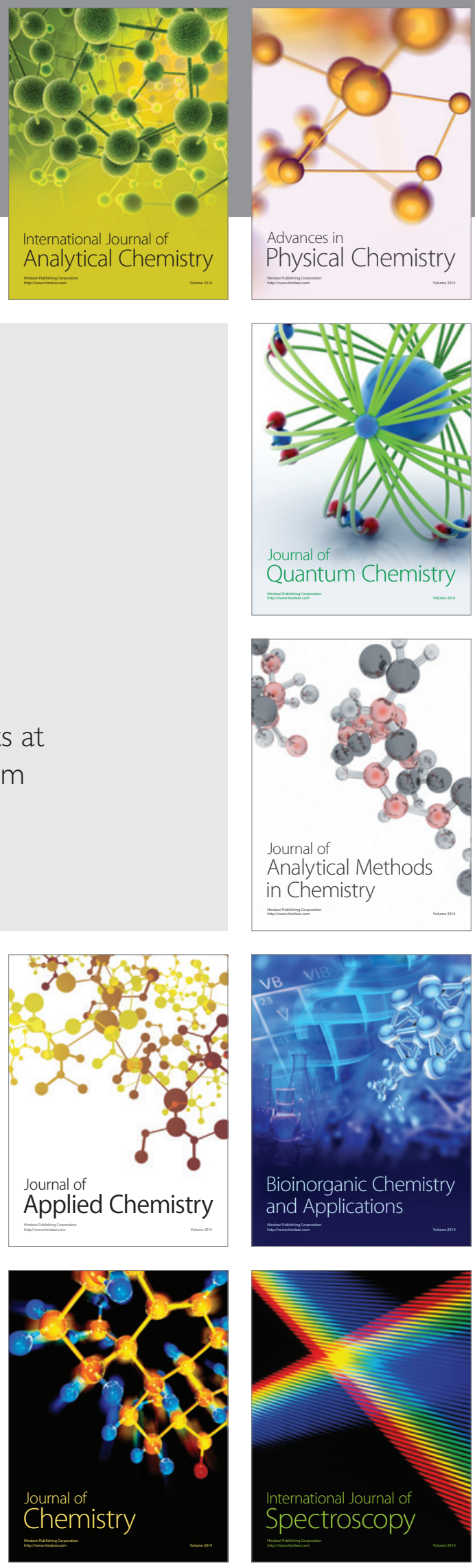